Review

\title{
Genetic Variants behind Cardiovascular Diseases and Dementia
}

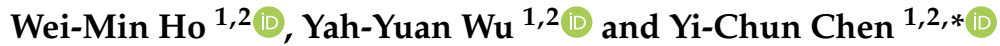 \\ 1 Department of Neurology, Chang Gung Memorial Hospital, Linkou Medical Center, Taoyuan 33305, Taiwan; \\ drho@cgmh.org.tw (W.-M.H.); lightsky85@hotmail.com (Y.-Y.W.) \\ 2 College of Medicine, Chang Gung University, Taoyuan 33302, Taiwan \\ * Correspondence: asd108@cgmh.org.tw; Tel.: +886-3-3281200 (ext. 8433)
}

Received: 9 November 2020; Accepted: 15 December 2020; Published: 18 December 2020

\begin{abstract}
Cardiovascular diseases (CVDs) and dementia are the leading causes of disability and mortality. Genetic connections between cardiovascular risk factors and dementia have not been elucidated. We conducted a scoping review and pathway analysis to reveal the genetic associations underlying both CVDs and dementia. In the PubMed database, literature was searched using keywords associated with diabetes mellitus, hypertension, dyslipidemia, white matter hyperintensities, cerebral microbleeds, and covert infarctions. Gene lists were extracted from these publications to identify shared genes and pathways for each group. This included high penetrance genes and single nucleotide polymorphisms (SNPs) identified through genome wide association studies. Most risk SNPs to both diabetes and dementia participate in the phospholipase $C$ enzyme system and the downstream nositol 1,4,5-trisphosphate and diacylglycerol activities. Interestingly, AP-2 (TFAP2) transcription factor family and metabolism of vitamins and cofactors were associated with genetic variants that were shared by white matter hyperintensities and dementia, and by microbleeds and dementia. Variants shared by covert infarctions and dementia were related to VEGF ligand-receptor interactions and anti-inflammatory cytokine pathways. Our review sheds light on future investigations into the causative relationships behind CVDs and dementia, and can be a paradigm of the identification of dementia treatments.
\end{abstract}

Keywords: Alzheimer's disease; cardiovascular disease; cerebral microbleedings; covert infarctions; dementia; single nucleotide polymorphisms; white matter hyperintensities

\section{Introduction}

With the advance of public health and medicine, the aging population has grown in recent decades; among this population, cardiovascular diseases (CVD) and dementia are the leading causes of disability and mortality [1,2]. The size of the global dementia population was predicted to hit 131 million by 2050. Cognitive and psychobehavioral dysfunctions in people with dementia impose a heavy burden on society [1]. Neuropathology in dementia is commonly heterogeneous, including amyloidopathy, tauopathy, or vasculopathy, and mixed dementia accounts for the major dementia type [3]. Nearly fifty percent of clinically diagnosed Alzheimer's disease (AD) patients consist of both AD pathology and cerebrovascular disease [4]. Mounting evidence has shown that cardiovascular risk factors (e.g., hypertension, diabetes mellitus, smoking, alcohol, hypercholesterolemia, and hyperhomocysteinemia) and genetics are associated with both CVD and dementia [2,5]. Moreover, cardiac diseases, such as heart failure, atrial fibrillation, or carotid occlusive diseases, may contribute to cognitive impairment through mechanisms associated with reduced cerebral perfusion or cerebrovascular occlusion $[6,7]$. Studies have found that interactions between the modifiable vascular risk factors and human genome exert extensive effects on the development and 
deterioration of neurodegenerative diseases [8]. Given that the genetic risk variants are nonmodifiable, prevention and correction of vascular risk factors will help to halt the development of dementia.

There are very few studies that have explicitly explored the genetic relationship between CVD and dementia. Specifically, in the genetic aspect, single nucleotide polymorphisms (SNPs) in different genes have been proven to play causal roles in both CVD and dementia. However, most of the studies recruited participants of the same ethnic origin, thereby rendering the results less prominent [9]. In addition, the interplay between multiple genetic and environmental factors complicates the investigation on the relationship of cardiovascular risk factors and cognitive impairment [10]. Although the evidence levels vary, meta-analyses studies have summarized such findings. A 20-year cohort, which evaluated almost 2 million SNPs in 9317 elderly individuals ( $>65$ years old), revealed that susceptible genetic variants of coronary artery disease, obesity, and type 2 diabetes (T2D) were associated with long-term functional status [11]. Additionally, the Framingham Heart Study reported that participants who had more cardiovascular risk factors or carried at least one Apolipoprotein E (APOE) $\varepsilon 4$ allele had a greater than two-fold risk of developing dementia [12]. Moreover, aging, APOE $\varepsilon 4$ allele, risk alleles in genome-wide association studies (GWAS), and cardiovascular risks increased the 10-year absolute risk of all-cause dementia [8]. These large cohort studies suggested that polygenic variants affecting cardiovascular health status, such as T2D, hypertension, and hyperlipidemia may also influence dementia risks. Thus, we reviewed the literature and summarized a list of genes and SNPs associated with each disease, and undertook further analysis to identify overlapping genes and their associating pathways.

\section{Materials and Methods}

We searched the PubMed database within the time frame from January 1990 to August 2020, and used the following combinations of keywords and Medical Subject Headings (MeSH) terms for a scoping review: "Alzheimer's disease", "cerebral autosomal dominant arteriopathy with subcortical infarcts and leukoencephalopathy", "CADASIL", "cerebrovascular disease", "cerebral microbleeds", "cerebrovascular risk factor", "cerebral small vessel disease (SVD)", "cerebral SVD", "cognition", "dementia", "genome-wide association studies", "GWAS", "neurodegenerative disorder", "silent/covert lacunar infarctions", "single nucleotide polymorphisms", "SNP", "vascular dementia", "white matter hyperintensities", and "white matter lesions". Besides the original clinical research studies, we also included randomized controlled trials and meta-analyses. Moreover, important literature cited in the article references were also reviewed if appropriate. No language restrictions were applied.

After extracting the SNPs and associated genes from the selected manuscripts, we categorized and summarized these genetic variants which were shared by each cardiovascular risk factor and dementia, for example, genes that were reported to be influential in causing cognitive decline in diabetic patients. We aimed to explore important genes that are pivotal to disease pathways and thus included high penetrance genes and SNPs from GWASs for pathway analysis by using the Reactome pathway database (https://reactome.org/) [13]. The Reactome Knowledgebase was curated by experts of different domains and was formalized into the database structure. The Reactome entities included nucleic acids, proteins, complexes, vaccines, and small molecules. All the networks were faithful to the primary literature and were further grouped into pathways [13]. We input the gene lists extracted from our review into Reactome and restricted the analysis to human beings. After obtaining the metabolic pathways from Reactome, we inspected the results and summarized the specific pathways according to each cardiovascular risk factor.

\section{Results}

\subsection{Genetic Variants Connecting Cardiovascular Risk Factors and Dementia}

The genetic variants associated with cardiovascular risk factors are heterogeneous, and no single gene or polymorphism can explain the whole picture. Among the variants investigated, the most influential cardiovascular risk to dementia was T2D-related genes. 


\subsubsection{Diabetes Mellitus}

We found 9568 articles discussing T2D and SNPs, among which 53 articles focused on cognitive decline or $\mathrm{AD}$. After reviewing these articles, we retained 10 representative articles and excluded similar ones.

T2D has been recognized as a risk factor of CVD, cerebrovascular disease, and dementia, and the underlying genetic mechanisms remain unknown. However, T2D does not fully explain the development of dementia in that other causal factors, such as amyloid $\beta$ plaques, tau tangles, cerebral amyloid angiopathy, cerebral SVD, or chronic cerebral perfusion insufficiency also contribute to the pathophysiology of cognitive decline [14]. A GWAS analyzing AD and T2D found that both diseases shared 395 SNPs involved in immunity, cell signaling, cellular processes, and neuronal plasticity (Supplementary Table S1) [15]. Furthermore, a meta-analysis reported that eight SNPs, including TP53INP1 and TOMM40, were associated with both AD and T2D (Supplement Table S2), suggesting that common risk genes were shared by $\mathrm{AD}$ and T2D [16].

T2D may aggravate cognitive decline in diabetic people [17,18]. In T2D patients with normal cognition, rs17518584 of the CADM2 gene was associated with poor processing speed, semantic categorization, and executive functions [17]. In the degenerating population, rs391300 polymorphism of the Serine Racemase (SRR) gene was associated with T2D and the progression of mild cognitive impairment $(\mathrm{MCI})$ to $\mathrm{AD}$ [18]. In addition, the insulin resistance pathway, such as serine/threonine-protein kinase (AKT) phosphorylation, also plays an important role in dementia risk [19]. AKT1 rs2498786 CC genotype was a risk variant to insulin resistance and AD [20]. Moreover, patients carrying the TT genotype of Transcription factor 7-like 2 (TCF7L2), a diabetes-associated gene, in a cardiovascular cohort had poor executive, attention, and processing speed functions compared to those with CC and CT genotypes [21]. Haptoglobin (Hp) protein is encoded at the chromosome 16q22 locus, and $H p-1$ and $H p-2$ are the two alleles on this locus. Haptoglobin can bind free form hemoglobin and thus prevent tissue from oxidative damage [22]. The elderly diabetic African Americans carrying the Hp 1-1 genotype had significant cognitive decline compared to those who carried other genotypes, indicating that aging may influence $H p$ expression [23]. Besides aging, risk SNPs may interact with other risk factors to compromise cognition. The synergic effect of serum glycated hemoglobin ( $\mathrm{HbA} 1 \mathrm{c})$ level, $A P O E$ gene, and $\mathrm{Val}(66) \mathrm{Met}$ in the Brain-derived neurotrophic factor (BDNF) gene may accelerate the rates of episodic memory decline [24].

In this study, we performed pathway analysis based on genes that we appraised from reviewed literature (Table 1, Supplementary Tables S1 and S2). We found that most of the above genes participate in the phospholipase $C$ enzyme system and the downstream second messengers, inositol 1,4,5-trisphosphate (IP3) and diacylglycerol (DAG) activities. IP3 mediates intracellular calcium storage while DAG activates protein kinase $\mathrm{C}$ isoforms. The calcium concentration also triggers calmodulin-calcium interaction, which modulates synaptic plasticity, learning, and memory (Supplementary Table S3) [25]. In addition, triggering receptor expressed on myeloid cells 2 (TREM2) gene has been shown to protect neurons from inflammation and to ameliorate memory impairment in AD mice through interacting with the AKT gene in the PI3K/AKT/FoxO3a signaling pathway [26]. Moreover, blockage of tropomyosin-related kinase (Trk) receptors type B of the BDNF gene from $\delta$-secretase cleavage may prevent production of $\beta$-amyloid [27]. The above evidence shows that T2D influences the dementia progress through various metabolic pathways.

\subsubsection{Inflammation}

We searched the PubMed database for articles that investigated the association between genetics and inflammatory mediators in dementia. Sixty-seven articles were initially identified which, after title, abstract and paper review, resulted in six papers. 
Table 1. Genes Associated with both Diabetes Mellitus and Dementia.

\begin{tabular}{|c|c|c|c|c|c|}
\hline Gene & Location & Marker $^{1}$ & rOR * & Gene-Phenotype Relationships ${ }^{2}$ & Ref \\
\hline AKT1 & $14 q 32.33$ & rs2498786 & $\begin{array}{c}0.33 \\
(0.16-0.70)\end{array}$ & $\begin{array}{l}\text { Breast cancer, colorectal cancer, } \\
\text { Cowden syndrome 6, ovarian } \\
\text { cancer, proteus syndrome }\end{array}$ & [20] \\
\hline Gene & Location & Marker $^{1}$ & $\mathbf{r} \beta$ * & Gene-Phenotype Relationships ${ }^{2}$ & Ref \\
\hline CADM2 & 3p12.1 & rs17518584 & 0.06 & & [17] \\
\hline Gene & Location & Marker $^{1}$ & $\mathbf{r P} *$ & Gene-Phenotype Relationships ${ }^{2}$ & Ref \\
\hline$H P$ & $16 q 22.2$ & Hp 1-1 & $<0.01$ & $\begin{array}{l}\text { Anhaptoglobinemia, } \\
\text { Hypohaptoglobinemia }\end{array}$ & [23] \\
\hline$S R R$ & $17 \mathrm{p} 13.3$ & rs391300 & $<0.01$ & & [18] \\
\hline TCF7L2 & $10 q 25.2-q 25.3$ & rs7903146 & $<0.01$ & Diabetes mellitus, type 2 & [21] \\
\hline$A P O E$ & $19 q 13.32$ & $\varepsilon 4$ & NA * & $\begin{array}{c}\text { Alzheimer disease, macular } \\
\text { degeneration }\end{array}$ & [24] \\
\hline$B D N F$ & 11p14.1 & Val(66)Met & NA & $\begin{array}{c}\text { Signaling by receptor tyrosine } \\
\text { kinases }\end{array}$ & [24] \\
\hline
\end{tabular}

${ }^{1}$ Marker means mutation or single nucleotide polymorphisms. ${ }^{2}$ Gene-phenotype relationships from Online Mendelian Inheritance in Man (OMIM). ${ }^{*}$ rOR, reported odds ratio; $r \beta$, reported $\beta$ value; rP, reported $p$ value; NA, statistics not available.

The role of inflammatory mediators in dementia and its interaction with amyloid plaques have been discussed extensively [28]. Various expressions of cytokines and chemokines, such as IL-1 and TNF- $\alpha$, were found in neurodegenerative disorders [29]. A study analyzing elderly participants in the Cardiovascular Health Study showed that rs17042917 and rs4251961 variants of the IL1RN gene were associated with the baseline cognitive status, supporting the proinflammatory cytokine IL-1 as a biomarker of dementia status [30]. The Paraoxonase (PON) gene cluster of lactonases comprises three genes, PON1, PON2, and PON3, on chromosome 7. PONs have a protective effect on the cardiovascular system and are associated with coronary heart disease, familial hypercholesterolemia, T2D, and atherosclerosis [31]. Vascular dementia (VaD) and AD were associated with different genotypes at codon 192 of the PON1 gene in that homozygous glutamine-glutamine at codon 192 was associated with $\mathrm{VaD}$, whereas homozygous arginine-arginine was more associated with $\mathrm{AD}$ [32]. Moreover, replacement of Cys to Ser at codon 311 of the PON2 gene occurred more frequently in VaD and in APOE $\varepsilon 4$ carriers of AD than in the controls (Table 2) [33]. The interaction between systemic inflammation and the brain was achieved mainly by cytokines and inflammatory mediators crossing the blood-brain barrier. Genetic variants associated with these inflammatory factors render more extensive investigations.

Table 2. Genes Associated with Hypercholesterolism, Hypertension, Inflammation, and Dementia.

\begin{tabular}{|c|c|c|c|c|c|}
\hline \multicolumn{6}{|c|}{ Inflammation } \\
\hline Gene & Location & Marker $^{1}$ & $\mathrm{rOR}^{*}$ & $\begin{array}{l}\text { Gene-Phenotype } \\
\text { Relationships }{ }^{2}\end{array}$ & Ref \\
\hline$I L 1 R N$ & $2 q 14.1$ & $\begin{array}{l}\text { rs17042917, } \\
\text { rs4251961 }\end{array}$ & $0.47(0.09-0.85)$ & & [30] \\
\hline PON1 & $7 q 21.3$ & 192QQ/RR & NA * & $\begin{array}{c}\text { Coronary artery disease, } \\
\text { Coronary artery spasm } 2, \\
\text { Microvascular complications } \\
\text { of diabetes } 5\end{array}$ & [32] \\
\hline PON2 & $7 q 21.3$ & 311 (Cys $\rightarrow$ Ser $)$ & NA & Coronary artery disease & [33] \\
\hline
\end{tabular}


Table 2. Cont.

\begin{tabular}{|c|c|c|c|c|c|}
\hline \multicolumn{6}{|c|}{ Hypertension } \\
\hline Gene & Location & Marker $^{1}$ & $\mathrm{rP}^{*}$ & $\begin{array}{l}\text { Gene-Phenotype } \\
\text { Relationships }^{2}\end{array}$ & Ref \\
\hline PSEN2 & & rs6703170 & $<0.01$ & & [34] \\
\hline WWC1 & $5 q 34$ & rs17070145 & $<0.01$ & Memory & [35] \\
\hline Clock & $4 q 12$ & T3111C & 0.03 & & [36] \\
\hline \multicolumn{6}{|c|}{ HypercholesteRolemia } \\
\hline Gene & Location & Marker $^{1}$ & $\mathrm{rOR}^{*}$ & $\begin{array}{l}\text { Gene-Phenotype } \\
\text { Relationships }{ }^{2}\end{array}$ & Ref \\
\hline CETP & $16 q 13$ & rs5882 & $0.29(0.10-0.85)$ & $\begin{array}{l}\text { High density lipoprotein } \\
\text { cholesterol, } \\
\text { Hyperalphalipoproteinemia }\end{array}$ & [37] \\
\hline$L R P 1 B$ & $2 q 22.1-q 22.2$ & $\begin{array}{l}\text { rs12474609, } \\
\text { rs10201482, } \\
\text { rs980286 }\end{array}$ & $\begin{array}{l}0.63(0.38-1.03), \\
0.71(0.47-1.09), \\
0.77(0.50-1.18)\end{array}$ & & [38] \\
\hline
\end{tabular}

${ }^{1}$ Marker means mutation or single nucleotide polymorphisms. ${ }^{2}$ Gene-phenotype relationships from Online Mendelian Inheritance in Man (OMIM). ${ }^{*}$ rOR, reported odds ratio; $r P$, reported $p$ value; NA, statistics not available.

\subsubsection{Hypertension and Hyperlipidemia}

We searched the PubMed database for articles that investigated the association between genetics and hypertension. Thirty-four articles were initially identified and after abstract and paper review, we found five papers discussing cognitive decline or $\mathrm{AD}$ in hypertension patients.

Hypertension is one of the major modifiable risk factors leading to dementia [1]. The interaction between blood pressure and genetic variants on cognition has not been revealed. One study showed that individuals with homozygotic Val allele of the BDNF gene had better associative memory and faster processing speed than the Met allele carriers, especially in female or hypertensive participants [39]. Another study reported that the T allele of rs 17070145 of WW and C2 domain containing one (WWC1 or $K I B R A$ ) gene was associated with lower executive function, especially in women with hypertension [35]. A linkage analysis study also showed that serum A $\beta 40$ levels in nondemented hypertensive patients were associated with rs6703170 of the presenilin 2 (PSEN2) gene and rs2514299 on chromosome 11q14-21 area [34]. Common diseases may share the same risk genetic variants, for example, by applying family-based association tests, one study found that rs2033610, rs2596164, and rs2278317 variants of the Ryanodine receptor 3 ( $R Y R 3$ ) gene were associated with risk of hypertension, T2D, and AD [40]. In addition, C-carriers of Clock Circadian Regulator (Clock) T3111C polymorphism who had hypertension and $A P O E \varepsilon 4$ carriers with dyslipidemia had a higher risk of conversion to AD. These results showed that Clock T3111C and APOE status may interact with hypertension and dyslipidemia to promote the conversion of MCI to AD (Table 2) [36].

We searched the PubMed database for articles which investigated the association between genetics and hyperlipidemia. Twelve articles were initially identified and after abstract and paper review, we found two papers reporting genetic variants that might lower cognitive decline. A microarray study reported that three SNPs (rs12474609, rs10201482, and rs980286) in the Low-density lipoprotein receptor-related protein $1 \mathrm{~B}(L R P 1 B)$ gene may have a cognition protective effect against AD [38]. Moreover, variants in the Cholesteryl ester transfer protein (CETP) gene were associated with lower risk of cardiovascular events and long life [41]. There is a substitution of isoleucine to valine in SNP rs5882 at codon 405 of the CETP gene. A prospective cohort reported that individuals with homozygous variants had slower deterioration of memory and a lower risk of developing dementia (Table 2) [37]. 


\subsection{Cerebral Small Vessel Diseases and Dementia}

Cerebral SVDs are proposed as a surrogate or biomarker of stroke and dementia. The hallmark of cerebral SVD is mainly endothelial changes in the cerebral arterioles and microvessels that present different features on magnetic resonance imaging (MRI), such as white matter hyperintensities (WMHs), cerebral microbleeds (CMBs), covert infarcts (CIs), and large perivascular space [42,43]. Large perivascular spaces were associated with rapid deterioration of information processing speed and a four-fold risk of developing VaD [44]. Various risk factors for cerebral SVD have been reported including age, atheromatous vesicular change, cerebral amyloid angiopathy, T2D, vasculitis, infections, hypertension, and several genetic diseases such as CADASIL (cerebral autosomal dominant arteriopathy with subcortical infarcts and leukoencephalopathy) [45].

CADASIL is a rare autosomal dominant reversible cerebral angiopathy with the symptoms of ischemic stroke, cognitive decline, migraine, and psychiatric disturbances [46]. In a cohort of 276 CADASIL patients, more than $91 \%$ of the lacunes were found at the edge of $\mathrm{WMH}$, rendering the possible association between infarction and WMH lesions [47]. Mutations in the NOTCH3 gene on chromosome 19 are believed to be the main cause of CADASIL [48]. In addition to the NOTCH3 gene, some minor variants have been proposed to exert polygenic contributions to WMH burden in CADASIL [49]. In common variants, such as in the APOE gene, carriers of the APOE $\varepsilon 4$ allele and of homozygous $A P O E \varepsilon 4$ genotype had more WMH volume and CMBs, whereas APOE $\varepsilon 2$ carriers had more WMH burden and increased risk of ischemic infarctions [50].

\subsubsection{Genetic Variants Connecting White Matter Hyperintensities and Dementia}

We found 217 articles investigating WMHs-related SNPs, of which nine articles discussed cognitive decline or AD.

In a monozygotic twin study and population cohort, larger WMH volume was associated with cardiovascular risk factors and poor cognitive functions [51,52]. In a preclinical AD population, $\mathrm{WMH}$ volume and APOE $\varepsilon 4$ variant were more associated with cerebral $\mathrm{A} \beta$ deposition [53]. However, $\mathrm{WMH}$ may also play a role in non-AD dementia. One study reported that, in MCI patients, those who converted into non-AD dementia may have larger $\mathrm{WMH}, \mathrm{CMBs}$, and basal ganglion infarcts than those that remained in MCI. Moreover, mesial temporal lobe atrophy was associated with the progression to $\mathrm{AD}$ while $\mathrm{WMHs}$ were associated with non-AD dementia [54]. In a study of frontotemporal dementia (FTD), symptomatic FTD patients with GRN mutation had more WMH load than patients with microtubule-associated protein tau (MAPT) and chromosome 9 open reading frame 72 (C9orf72) gene mutations. In addition, more WMHs were found in the frontal and occipital lobes than in other brain areas [55]. In a case report study, a homozygous variant of c.847G $>\mathrm{T}$ in the HtrA serine protease 1 (HTRA1) gene was found in a patient with symptoms of Cerebral autosomal recessive arteriopathy with subcortical infarcts and leukoencephalopathy (CARASIL) and WMHs in MRI [56]. The polygenic risk effect on cognition can be mediated by $\mathrm{WMHs}$ and $\mathrm{CMBs}$, and the risk alleles for $\mathrm{AD}$, regardless of whether they reside within or outside the APOE-linkage region (19q13), have been influenced by CMBs, WMH, and coronary artery calcification (Table 3) [57]. Pathway analysis did not show profound downstream metabolic networks, partly due to few genes found to be connected with WMHs and dementia (Supplement Table S4). More specific results were that NOTCH3 and APOE genes both participated in the regulation of AP-2 (TFAP2) transcription factor family, and MTHFR and APOE genes were involved in metabolism of vitamins and cofactors. The AP-2 protein has been shown to function with Phosphatidylinositol clathrin assembly lymphoid-myeloid leukemia (PICALM) as an autophagic cargo receptor in the degradation of amyloid $\beta$ clearance [58].

\subsubsection{Genetic Variants Connecting Cerebral Microbleeds and Dementia}

Seventeen articles were found with CMBs-associating SNPs, of which nine articles focused on cognitive decline or AD. 
Table 3. Genes Associated with both to White Matter Hyperintensities and Dementia.

\begin{tabular}{|c|c|c|c|c|c|}
\hline Gene & Location & Marker $^{1}$ & rOR * & Gene-Phenotype Relationships ${ }^{2}$ & Ref \\
\hline$A P O E$ & $19 q 13.32$ & $\varepsilon 4$ allele & $1.24(1.07-1.43)$ & $\begin{array}{l}\text { Alzheimer disease, macular } \\
\text { degeneration, coronary artery } \\
\text { disease, hyperlipoproteinemia, } \\
\text { lipoprotein glomerulopathy }\end{array}$ & [50] \\
\hline Gene & Location & Marker $^{1}$ & $\mathbf{r P} *$ & Gene-Phenotype Relationships ${ }^{2}$ & Ref \\
\hline GRN & $17 q 21.31$ & Progranulin & $<0.01$ & $\begin{array}{l}\text { Aphasia, primary progressive, } \\
\text { ceroid lipofuscinosis, neuronal, } \\
\text { frontotemporal lobar degeneration } \\
\text { with ubiquitin-positive inclusions }\end{array}$ & [55] \\
\hline HTRA1 & $10 \mathrm{q} 26.13$ & c. $847 \mathrm{G}>\mathrm{T}$ & $\mathrm{NA}^{*}$ & $\begin{array}{l}\text { Macular degeneration, CARASIL } \\
\text { syndrome }\end{array}$ & [56] \\
\hline NOTCH3 & 19 p13.12 & & $<0.01$ & $\begin{array}{l}\text { Myofibromatosis, infantile 2, } \\
\text { CADASIL, lateral meningocele } \\
\text { syndrome }\end{array}$ & [49] \\
\hline
\end{tabular}

${ }^{1}$ Marker means mutation or single nucleotide polymorphisms. ${ }^{2}$ Gene-phenotype relationships from Online

Mendelian Inheritance in Man (OMIM). * rOR, reported odds ratio; rP, reported $p$ value; NA, statistics not available.

CMBs are represented as small vessel wall damage with various degrees of $\beta$-amyloid accumulation, and different vascular risk factors are believed to impose causative effects on cerebral CMBs [59]. While nonlobar microbleeds were associated with cardiovascular mortality, lobar microbleeds were associated with the risk of mortality by stroke [59]. The Rotterdam Study reported that more than four CMBs per subject was associated with cognitive deterioration. They also found that lobar CMBs were associated with impairments in execution, information processing, and memory, while nonlobar CMBs were associated with decline in information processing and motor speed [60].

A GWAS showed that APOE $\varepsilon 4$ alleles were associated with lobar CMB numbers and the rs769449 variant in $A P O E$ was significantly associated with CMBs [61]. Stroke patients with $\varepsilon 2$ and $\varepsilon 4$ alleles were reported to have more lobar CMBs in one Korean cohort [62]. Moreover, carriers of the $\varepsilon 4$ allele of $A P O E$ may have more CMBs than carriers of the $\varepsilon 3 / \varepsilon 3$ genotype, and the association was stronger in lobar CMBs [63]. Among hypertensive patients aged between 55 and 75 years old, homozygous carriers of the APOE $\varepsilon 4$ allele had more lacunes than heterozygous $\varepsilon 2 / \varepsilon 4$ carriers. In addition, individuals with homozygous variant alleles of four SNPs (rs1699102, rs3824968, rs2282649, and rs1010159) within the $3^{\prime}$-end of the SORL1 gene had more CMBs than other individuals. This relationship between $A P O E$, SORL1, and CMBs implies that the amyloid theory may play a role in the mechanism of CMBs, especially in hypertensive patients [64].

Several genetic loci other than in the APOE region have been connected to CMBs. A GWAS showed that 19 SNPs were associated with CMBs, whereas the rs55738218 of SLC12A7 was associated with decreased progression risk of CMBs (Table 4) [65]. The TT genotype of the methylenetetrahydrofolate reductase (MTHFR) gene and the presence of CMBs were associated with hyperhomocysteinemia in patients with memory impairment [66]. A study of Taiwanese CADASIL showed that NOTCH3 mutation carriers had more $\mathrm{CMBs}$ in the thalamus and temporal lobe with a wide variation in $\mathrm{CMB}$ counts. The $\mathrm{CMB}$ counts per $\mathrm{CMB}$ volume increased as the disease deteriorated, and the $\mathrm{CMB}$ counts increased more rapidly in the thalamus, temporal, and frontal lobes [67]. One study found a frame shift variant (c.236_237delAC) in the CCM2 gene from three siblings with cognition decline, multiple $\mathrm{CMBs}$, and a family history of early onset $\mathrm{AD}$ [68]. Moreover, the homozygous $\varepsilon 4$ genotype of $A P O E$ was found in two siblings and was heterozygous in a third sibling. This study showed that CMBs and dementia may be attributed to the interaction between the CCM2 variant and the APOE genotype [68]. Polymorphic variants of Aldehyde dehydrogenase $2(A L D H 2)$ were found to be associated with alcoholic cardiomyopathy and stroke [69], and hypertensive male carriers of rs671 in the $A L D H 2^{*} 1{ }^{*} 1$ genotype were more likely to have CMBs than $A L D H 2 * 2$ allele carriers (Table 4) [70]. 
Table 4. Genes Associated with both to Cerebral Microbleeds and Dementia.

\begin{tabular}{|c|c|c|c|c|c|}
\hline Gene & Location & Marker $^{1}$ & rOR * & $\begin{array}{l}\text { Gene-Phenotype } \\
\text { Relationships }^{2}\end{array}$ & Ref \\
\hline$A L D H 2$ & $12 q 24.12$ & rs671 & $1.93(1.21-3.06)$ & $\begin{array}{l}\text { Esophageal cancer, } \\
\text { alcohol-related, hangover, } \\
\text { sublingual nitroglycerin, } \\
\text { alcohol sensitivity }\end{array}$ & [69] \\
\hline$A M P H$ & & rs10263645 & 0.41 & & [65] \\
\hline$A P O E$ & $19 q 13.32$ & rs769449 & NA* & $\begin{array}{c}\text { Alzheimer's disease, } \\
\text { macular degeneration, } \\
\text { coronary artery disease, } \\
\text { hyperlipoproteinemia, } \\
\text { lipoprotein } \\
\text { glomerulopathy }\end{array}$ & [62] \\
\hline CCM2 & $7 \mathrm{p} 13$ & $\begin{array}{l}\text { Frame shift } \\
\text { variant } \\
\text { (c.236_237delAC) } \\
\end{array}$ & NA & $\begin{array}{l}\text { Cerebral cavernous } \\
\text { malformations-2 }\end{array}$ & [68] \\
\hline CTNNA2 & $2 \mathrm{p} 12$ & rs1368908 & 2.21 & $\begin{array}{c}\text { Cortical dysplasia, } \\
\text { complex }\end{array}$ & [65] \\
\hline LINC01361 & 1p31.1 & $\begin{array}{l}\text { rs10493734, } \\
\text { rs10782802 }\end{array}$ & $0.46,0.48$ & & [65] \\
\hline LINC01362 & 1p31.1 & $\begin{array}{l}\text { rs1144266, } \\
\text { rs1144267, } \\
\text { rs7411897, } \\
\text { rs11163625, } \\
\text { rs1348045, } \\
\text { rs11163602 }\end{array}$ & $\begin{array}{c}0.45,0.47,0.47,0.47 \\
0.48,0.48\end{array}$ & & [65] \\
\hline LOC105374287 & $3 q 29$ & rs12497385 & 0.51 & & [65] \\
\hline LOC105374510 & 4p15.31 & $\begin{array}{l}\text { rs1850549, } \\
\text { rs66690887, } \\
\text { rs67159217, } \\
\text { rs10027565 }\end{array}$ & $2.56,2.05,2.05,1.97$ & & [65] \\
\hline LOC107985396 & 1p31.1 & $\begin{array}{l}\text { rs12132310, } \\
\text { rs12140057, } \\
\text { rs11163585 }\end{array}$ & $0.46,0.47,0.47$ & & [65] \\
\hline SLC12A7 & $5 p 15.33$ & rs55738218 & 0.22 & & [65] \\
\hline SORL1 & $11 q 24.1$ & $\begin{array}{l}\text { rs1699102, } \\
\text { rs3824968, } \\
\text { rs2282649, } \\
\text { rs1010159 }\end{array}$ & $\begin{array}{c}6.81(1.79-25.97), 5.90 \\
(1.54-22.70), 6.87 \\
(1.78-26.44), 4.17 \\
(1.18-14.70)\end{array}$ & & [64] \\
\hline SRGAP1 & $12 \mathrm{q} 14.2$ & rs6581525 & 2.05 & & [65] \\
\hline
\end{tabular}

1 Marker means mutation or single nucleotide polymorphisms. ${ }^{2}$ Gene-phenotype relationships from Online Mendelian Inheritance in Man (OMIM). ${ }^{*}$ rOR, reported odds ratio; NA, statistics not available.

Interestingly, pathway analysis showed that NOTCH3 and APOE genes were both involved in Adaptor protein-2 (AP-2) transcription regulation and vitamins, which were the same metabolic pathways found in WMHs (Supplement Table S5). The analysis suggested that metabolic factors, including vitamins, cofactors, signal transduction by growth factor receptors and vesicle-mediated transport, may contribute to CMBs-associated dementia.

\subsubsection{Genetic Variants Connecting Covert Infarction and Dementia}

We searched the PubMed database for articles which investigated the association between genetics and CIs. Thirty-six articles were initially identified and after abstract and paper review we found six papers were associated with cognitive decline or AD.

Cerebral CIs are asymptomatic brain infarcts or the symptoms are too minor to draw the patients' attention [71]. The definition of CIs has not been reached and the inconsistent inclusion criteria has led to a difficulty in appraisal [71]. For instance, the sizes of atrial fibrillation (AF)-induced silent 
infarcts may vary from 1.1 to $170 \mathrm{~mL}$ [72]. One cohort showed that among AF patients with clinical silent infarctions, $15 \%$ had large noncortical or cortical infarcts and $18 \%$ had small noncortical infarcts. The AF-related large silent infarctions were associated with poor cognitive performance while the small ones were not [73]. Another difficulty of CI research is that CIs are mostly found incidentally and a portion of subjects with CIs may not be diagnosed throughout their life [74]. Moreover, the causative factors associated with CIs were heterogeneous [75]. Thus, we focused on the genetics in small CIs-related dementia.

In addition to coronary artery disease and myocardial infarction, insulin resistance-related genetic variants were also associated with increased risk of CIs [76]. Specifically, GG genotypes of rs3219175 and rs34861192 of the Resistin (RETN) gene, encoding a hormone that links obesity to diabetes mellitus, were associated with increased risk of small artery ischemic stroke [77]. The Apolipoprotein A-I (APOA1) gene encodes the main protein component of high-density lipoprotein in plasma, which facilitates the function of cholesterol excretion. One study showed that variants of APOA1 were associated with CIs [78]. The Mono-ADP Ribosylhydrolase 2 (MACROD2) gene encodes a deacetylase that mediates removal of ADP-ribose from mono-ADP-ribosylated proteins. In addition, mutations of MACROD2 may cause hypercholesterolemia. A community based GWAS revealed that $\mathrm{T}$ allele carriers of MACROD2 rs2208454 polymorphism and 22 other SNPs with linkage disequilibrium had a lower risk of CIs (Table 5) [79].

Table 5. Genes Associated both to Covert Infarcts and Dementia.

\begin{tabular}{|c|c|c|c|c|c|}
\hline Gene & Location & Marker ${ }^{1}$ & $\mathrm{rOR}^{*}$ & Gene-Phenotype Relationships ${ }^{2}$ & Ref \\
\hline$A D D 1$ & $4 p 16.3$ & Gly460Trp & $1.36(0.98-1.88)$ & Hypertension & [80] \\
\hline ADM2 & $22 \mathrm{q} 13.33$ & rs3840963 & $2.4(1.2-4.7)$ & & [81] \\
\hline ADRA2 & 10q25.2 & rs61767072 & $2.03(1.34-3.10)$ & & [82] \\
\hline APOA1 & $11 \mathrm{q} 23.3$ & $\begin{array}{l}\text { Alleles I to } \\
\text { IV }\end{array}$ & $2.56(1.19-5.53)$ & $\begin{array}{c}\text { Amyloidosis, ApoA-I and apoC-III } \\
\text { deficiency, } \\
\text { hypoalphalipoproteinemia }\end{array}$ & [78] \\
\hline eNOS & $7 \mathrm{q} 36.1$ & $894 \mathrm{G}>\mathrm{T}$ & $2.27(1.34-3.83)$ & $\begin{array}{c}\text { Alzheimer's disease, late-onset, } \\
\text { coronary artery spasm 1, } \\
\text { hypertension, ischemic stroke, } \\
\text { placental abruption }\end{array}$ & [83] \\
\hline$K D R$ & $4 q 12$ & $-604 \mathrm{~T}>\mathrm{C}$ & $\begin{array}{c}1.596 \\
(1.02-2.50)\end{array}$ & Hemangioma, capillary infantile & [84] \\
\hline MACROD2 & $20 \mathrm{p} 12.1$ & rs2208454 & $0.76(0.68-0.84)$ & & [79] \\
\hline MTHFR & $1 \mathrm{p} 36.22$ & $\mathrm{C} 677 \mathrm{~T}$ & $1.72(1.10-2.68)$ & $\begin{array}{l}\text { Vascular disease, homocystinuria, } \\
\text { neural tube defects, schizophrenia, } \\
\text { thromboembolism }\end{array}$ & [85] \\
\hline $\mathrm{PRKCH}$ & $14 \mathrm{q} 23.1$ & $\begin{array}{l}\text { rs3783799, } \\
\text { rs2230500 }\end{array}$ & $\begin{array}{l}1.83(1.00-3.38) \\
1.62(1.21-2.17)\end{array}$ & Cerebral infarction & [86] \\
\hline RETN & $19 \mathrm{p} 13.2$ & $\begin{array}{l}\text { rs3219175, } \\
\text { rs34861192 }\end{array}$ & $\begin{array}{l}1.49(1.03-2.17) \\
1.46(1.01-2.13)\end{array}$ & Diabetes mellitus, Hypertension & [77] \\
\hline SLC19A1 & $21 \mathrm{q} 22.3$ & $80 \mathrm{~A}>\mathrm{G}$ & $\begin{array}{c}1.384 \\
(1.03-1.87)\end{array}$ & & [87] \\
\hline$T B X A 2 R$ & $19 \mathrm{p} 13.3$ & rs768963 & $\mathrm{NA}^{*}$ & Bleeding disorder, platelet-type & [88] \\
\hline
\end{tabular}

Hyperhomocysteinemia has been found to be associated with CIs [89]. In folate metabolism, the Reduced folate carrier (SLC19A1) gene encodes the subunit of replication factor C and facilitates folate delivery to cells. One study showed that a polymorphism of the RFC-1 gene ( $80 \mathrm{~A}>\mathrm{G})$ was associated with arterioles and CIs [87]. The MTHFR gene encodes a protein that catalyzes homocysteine remethylation to methionine, and mutation of MTHFR is known to induce occlusive vascular disease. 
A study in a Japanese cohort reported that TT genotype carriers of MTHFR C677T polymorphism had higher risks of developing CI and WMH, especially in the elderly (>60 years old) [85].

Atherosclerosis and hypercoagulation status may promote arterial thrombosis. The thromboxane A2 receptor (TBXA2R) gene regulated platelet aggregation, and the $C$ allele of rs768963 polymorphism of TBXA2R was associated with both large artery atherosclerosis and small artery occlusion [88]. The vascular endothelial growth factor $(V E G F)$ gene encodes a heparin-binding protein that induces proliferation and migration of vascular endothelial cells and angiogenesis. The $C$ allele of rs2010963 and T allele of rs3025039 of the VEGF gene were associated with small-artery occlusions and CIs [90]. Moreover, the $C$ allele of the $-604 \mathrm{~T}>\mathrm{C}$ (rs2071559) polymorphism of Kinase insert domain receptor $(K D R)$, which encodes the receptor of VEGF, was associated with increased risk of $\mathrm{CI}$ in younger ( $<65$ years old) and male patients [84]. In addition, the endothelial nitric oxide synthase (eNOS) gene, which is involved in the VEGF pathway, is known to promote angiogenesis in coronary arteries and blood clotting. The haplotypes constructed by the eNOS SNPs of -786T-4b-894G, $-786 \mathrm{~T}-4 \mathrm{~b}-894 \mathrm{~T}$, and -786C-4a-894T were significantly different between patients with CIs and the controls (Table 5) [83].

There are other genes that have been reported as susceptible to cerebral SVD (Table 5). Specifically, the deletion/deletion carriers of rs3840963 of Adrenomedullin 2 (ADM2), encoding proteins that regulate cardiovascular homeostasis and prolactin release, suffered from higher risk of chronic kidney disease, CI and WMH [81]. In addition, the c.971_982del of rs61767072 of the adrenoceptor- $\alpha 2$ (ADRA2) gene was associated with CIs when patients had hypertension and hyperhomocysteinemia, and the c.145A $>\mathrm{G}$ (rs1801252) polymorphism of the ADRB1 gene was associated with small artery occlusion [82]. The c.1378G $>$ T polymorphism of the $\alpha$-adducin (ADD1) gene has also been mentioned as risks of CIs and WMHs [80]. Furthermore, mutations in the PRKCH gene were associated with cerebral infarction. Protein Kinase $C$ Eta regulates keratinocyte differentiation by activating the MAP kinase cascade. The AA genotypes of rs3783799 and rs2230500 polymorphisms of PRKCH were associated with risks of CI in a Japanese population (Table 5) [86].

Pathway analysis revealed that VEGF ligand-receptor interactions and anti-inflammatory cytokines were associated with CI-related dementia (Supplement Table S6). A previous study showed that VEGF in cerebrospinal fluid may have a protective effect toward patients with early AD biomarkers [91]. In addition, inflammatory factors, such as TNF $\alpha$, IL-6, and IL-10, were associated with both early and late-onset AD [92]. The roles of VEGF and inflammatory factors in the AD cascade warranted further investigation.

\section{Conclusions}

In this review, we searched for and summarized the risk genes or polymorphisms connecting cardiovascular risk factors and dementia. Our results delineated the genetic associations between common diseases, such as T2D and cerebral SVD, and neurodegeneration. We also analyzed the potential metabolic pathways that may provide functional explanations to the risk genetic variants. The most substantial results come from diabetes-related polymorphisms that cover a wide spectrum of metabolic background. Genes such as GNAI2, PRKACG, or CALM3 participate in the phospholipase $\mathrm{C}$ enzyme system and the downstream IP3 and DAG activities. Among the genes associated with both CMBs and dementia, the NOTCH3 and APOE genes were both found to be involved in AP-2 transcription regulation, suggesting that vitamins, growth factors, and vesicle-mediated transport may contribute to CMBs-associated dementia. The VEGF and KDR genes were related to VEGF ligand-receptor interactions and anti-inflammatory cytokine pathways, which may contribute to CI-related dementia. For cerebral SVD, although not many risk SNPs have been found to date, more comprehensive investigations are warranted. Our review sheds light on future investigations into the causative relationships behind CVDs and dementia, and can be a paradigm of the identification of dementia treatments.

Supplementary Materials: The following are available online at http://www.mdpi.com/2073-4425/11/12/1514/s1, Table S1: Genes associated with both diabetes mellitus and dementia, Table S2: SNPs associated with both diabetes 
mellitus and dementia, Table S3: Pathway analysis of risk genes for both diabetes mellitus and dementia, Table S4: Pathway analysis of risk genes for both white matter hyperintensities and dementia, Table S5: Pathway analysis of risk genes for both cerebral microbleeds and dementia, Table S6: Pathway analysis of risk genes for both covert infarction and dementia.

Author Contributions: Conceptualization, W.-M.H. and Y.-C.C.; methodology, W.-M.H. and Y.-C.C.; software, W.-M.H.; data curation, Y.-Y.W.; writing-original draft preparation, W.-M.H.; writing-review and editing, W.-M.H. and Y.-C.C.; supervision, Y.-C.C. All authors have read and agreed to the published version of the manuscript.

Funding: This study was supported by the Ministry of Science and Technology, Executive Yuan, Taiwan (grant numbers MOST108-2314-B-182A-047, 108-2629-B-182A-005, and 109-2629-B-182A-001) and Chang Gung Medical Foundation, Taiwan (grant numbers CMRPG3J0932).

Conflicts of Interest: The authors declare no conflict of interest.

\section{References}

1. Livingston, G.; Sommerlad, A.; Orgeta, V.; Costafreda, S.G.; Huntley, J.; Ames, D.; Ballard, C.; Banerjee, S.; Burns, A.; Cohen-Mansfield, J.; et al. Dementia Prevention, Intervention, and Care. Lancet 2017, 390, 2673-2734. [CrossRef]

2. Samieri, C.; Perier, M.C.; Gaye, B.; Proust-Lima, C.; Helmer, C.; Dartigues, J.F.; Berr, C.; Tzourio, C.; Empana, J.P. Association of Cardiovascular Health Level in Older Age with Cognitive Decline and Incident Dementia. JAMA 2018, 320, 657-664. [CrossRef] [PubMed]

3. Lowe, V.J.; Lundt, E.S.; Albertson, S.M.; Przybelski, S.A.; Senjem, M.L.; Parisi, J.E.; Kantarci, K.; Boeve, B.; Jones, D.T.; Knopman, D.; et al. Neuroimaging Correlates with Neuropathologic Schemes in Neurodegenerative Disease. Alzheimers Dement. 2019, 15, 927-939. [CrossRef] [PubMed]

4. Schneider, J.A.; Arvanitakis, Z.; Leurgans, S.E.; Bennett, D.A. The Neuropathology of Probable Alzheimer Disease and Mild Cognitive Impairment. Ann. Neurol. 2009, 66, 200-208. [CrossRef] [PubMed]

5. Broce, I.J.; Tan, C.H.; Fan, C.C.; Jansen, I.; Savage, J.E.; Witoelar, A.; Wen, N.; Hess, C.P.; Dillon, W.P.; Glastonbury, C.M.; et al. Dissecting the Genetic Relationship between Cardiovascular Risk Factors and Alzheimer's Disease. Acta Neuropathol. 2019, 137, 209-226. [CrossRef] [PubMed]

6. Hooghiemstra, A.M.; Leeuwis, A.E.; Bertens, A.S.; Biessels, G.J.; Bots, M.L.; Brunner-La Rocca, H.P.; Greving, J.P.; Kappelle, L.J.; van Oostenbrugge, R.J.; van Rossum, A.C.; et al. Frequent Cognitive Impairment in Patients with Disorders along the Heart-Brain Axis. Stroke 2019, 50, 3369-3375. [CrossRef] [PubMed]

7. Kokkinidis, D.G.; Zareifopoulos, N.; Theochari, C.A.; Arfaras-Melainis, A.; Papanastasiou, C.A.; Uppal, D.; Giannakoulas, G.; Kalogeropoulos, A.P.; Fontes, J.D.T. Association between Atrial Fibrillation and Cognitive Impairment in Individuals with Prior Stroke: A Meta-Analysis and Meta-Regression Analysis. Stroke 2020, 51, 1662-1666. [CrossRef]

8. Juul Rasmussen, I.; Rasmussen, K.L.; Nordestgaard, B.G.; Tybjærg-Hansen, A.; Frikke-Schmidt, R. Impact of Cardiovascular Risk Factors and Genetics on 10-Year Absolute Risk of Dementia: Risk Charts for Targeted Prevention. Eur. Heart J. 2020, 41, 4024-4033. [CrossRef]

9. Gola, D.; Erdmann, J.; Läll, K.; Mägi, R.; Müller-Myhsok, B.; Schunkert, H.; König, I.R. Population Bias in Polygenic Risk Prediction Models for Coronary Artery Disease. Circ. Genom. Precis. Med. 2020. [CrossRef]

10. Musunuru, K.; Kathiresan, S. Genetics of Common, Complex Coronary Artery Disease. Cell 2019, 177, 132-145. [CrossRef]

11. Wehby, G.L.; Domingue, B.W.; Wolinsky, F.D. Genetic Risks for Chronic Conditions: Implications for Long-Term Wellbeing. J. Gerontol. A Biol. Sci. Med. Sci. 2018, 73, 477-483. [CrossRef] [PubMed]

12. Peloso, G.M.; Beiser, A.S.; Satizabal, C.L.; Xanthakis, V.; Vasan, R.S.; Pase, M.P.; Destefano, A.L.; Seshadri, S. Cardiovascular Health, Genetic Risk, and Risk of Dementia in the Framingham Heart Study. Neurology 2020, 95, e1341-e1350. [CrossRef] [PubMed]

13. Jassal, B.; Matthews, L.; Viteri, G.; Gong, C.; Lorente, P.; Fabregat, A.; Sidiropoulos, K.; Cook, J.; Gillespie, M.; Haw, R.; et al. The Reactome Pathway KnowledgeBase. Nucleic Acids Res. 2020, 48, D498-D503. [CrossRef] [PubMed]

14. Biessels, G.J.; Nobili, F.; Teunissen, C.E.; Simó, R.; Scheltens, P. Understanding Multifactorial Brain Changes in type 2 Diabetes: A Biomarker Perspective. Lancet Neurol. 2020, 19, 699-710. [CrossRef] 
15. Hao, K.; Di Narzo, A.F.; Ho, L.; Luo, W.; Li, S.; Chen, R.; Li, T.; Dubner, L.; Pasinetti, G.M. Shared Genetic Etiology Underlying Alzheimer's Disease and type 2 Diabetes. Mol. Asp. Med. 2015, 43-44, 66-76. [CrossRef] [PubMed]

16. Wang, X.F.; Lin, X.; Li, D.Y.; Zhou, R.; Greenbaum, J.; Chen, Y.C.; Zeng, C.P.; Peng, L.P.; Wu, K.H.; Ao, Z.X.; et al. Linking Alzheimer's Disease and type 2 Diabetes: Novel Shared Susceptibility Genes Detected by cFDR Approach. J. Neurol. Sci. 2017, 380, 262-272. [CrossRef]

17. Greenbaum, L.; Ravona-Springer, R.; Livny, A.; Shelly, S.; Sharvit-Ginon, I.; Ganmore, I.; Alkelai, A.; Heymann, A.; Schnaider Beeri, M. The CADM2 Gene Is Associated with Processing Speed Performance-Evidence among Elderly With type 2 Diabetes. World J. Biol. Psychiatry 2019, 20, 577-583. [CrossRef]

18. Girard, H.; Potvin, O.; Nugent, S.; Dallaire-Théroux, C.; Cunnane, S.; Duchesne, S.; Alzheimer's Disease Neuroimaging Initiative. Faster Progression From MCI to Probable AD for Carriers of a Single-Nucleotide Polymorphism Associated With type 2 Diabetes. Neurobiol. Aging 2018, 64, 157.e11-157.e17. [CrossRef]

19. Arvanitakis, Z.; Wang, H.Y.; Capuano, A.W.; Khan, A.; Taïb, B.; Anokye-Danso, F.; Schneider, J.A.; Bennett, D.A.; Ahima, R.S.; Arnold, S.E. Brain Insulin Signaling, Alzheimer Disease Pathology, and Cognitive Function. Ann. Neurol. 2020. [CrossRef]

20. Liu, S.Y.; Zhao, H.D.; Wang, J.L.; Huang, T.; Tian, H.W.; Yao, L.F.; Tao, H.; Chen, Z.W.; Wang, C.Y.; Sheng, S.T.; et al. Association Between Polymorphisms of the AKT1 Gene Promoter and Risk of the Alzheimer's Disease in a Chinese Han Population with Type 2 Diabetes. CNS Neurosci. Ther. 2015, 21, 619-625. [CrossRef]

21. Keary, T.A.; Gunstad, J.; Benitez, A.; Spitznagel, M.B.; McCaffery, J.; McGeary, J.E.; Poppas, A.; Paul, R.H.; Sweet, L.H.; Cohen, R.A. TCF7L2 Polymorphism and Cognitive Test Performance in Cardiovascular Disease. Psychogeriatrics 2012, 12, 93-98. [CrossRef] [PubMed]

22. Asleh, R.; Briasoulis, A.; Berinstein, E.M.; Wiener, J.B.; Palla, M.; Kushwaha, S.S.; Levy, A.P. Meta-Analysis of the Association of the Haptoglobin Genotype with Cardiovascular Outcomes and the Pharmacogenomic Interactions with Vitamin E Supplementation. Pharmgenom. Pers. Med. 2018, 11, 71-82. [CrossRef] [PubMed]

23. Beeri, M.S.; Lin, H.M.; Sano, M.; Ravona-Springer, R.; Liu, X.; Bendlin, B.B.; Gleason, C.E.; Guerrero-Berroa, E.; Soleimani, L.; Launer, L.J.; et al. Association of the Haptoglobin Gene Polymorphism with Cognitive Function and Decline in Elderly African American Adults With Type 2 Diabetes: Findings From the Action to Control Cardiovascular Risk in Diabetes-Memory in Diabetes (Accord-MIND) Study. JAMA Netw. Open 2018, 1, e184458. [CrossRef] [PubMed]

24. Persson, N.; Lavebratt, C.; Wahlin, A. Synergy Effects of HbA1C and Variants of APOE and BDNFVal66Met Explains Individual Differences in Memory Performance. Neurobiol. Learn. Mem. 2013, 106, 274-282. [CrossRef]

25. Wayman, G.A.; Lee, Y.S.; Tokumitsu, H.; Silva, A.J.; Soderling, T.R. Calmodulin-Kinases: Modulators of Neuronal Development and Plasticity. Neuron 2008, 59, 914-931. [CrossRef]

26. Wang, Y.; Lin, Y.; Wang, L.; Zhan, H.; Luo, X.; Zeng, Y.; Wu, W.; Zhang, X.; Wang, F. TREM2 Ameliorates Neuroinflammatory Response and Cognitive Impairment via PI3K/AKT/FoxO3a Signaling Pathway in Alzheimer's Disease Mice. Aging 2020, 12, 20862-20879. [CrossRef]

27. Xia, Y.; Wang, Z.H.; Liu, P.; Edgington-Mitchell, L.; Liu, X.; Wang, X.C.; Ye, K. TrkB Receptor Cleavage by Delta-Secretase Abolishes Its Phosphorylation of APP, Aggravating Alzheimer's Disease Pathologies. Mol. Psychiatry 2020. [CrossRef]

28. Perry, V.H.; Cunningham, C.; Holmes, C. Systemic Infections and Inflammation Affect Chronic Neurodegeneration. Nat. Rev. Immunol. 2007, 7, 161-167. [CrossRef]

29. Lucin, K.M.; Wyss-Coray, T. Immune Activation in Brain Aging and Neurodegeneration: Too Much or Too Little? Neuron 2009, 64, 110-122. [CrossRef]

30. Benke, K.S.; Carlson, M.C.; Doan, B.Q.; Walston, J.D.; Xue, Q.L.; Reiner, A.P.; Fried, L.P.; Arking, D.E.; Chakravarti, A.; Fallin, M.D. The Association of Genetic Variants in Interleukin-1 Genes With Cognition: Findings From the Cardiovascular Health Study. Exp. Gerontol. 2011, 46, 1010-1019. [CrossRef]

31. Regieli, J.J.; Jukema, J.W.; Doevendans, P.A.; Zwinderman, A.H.; Kastelein, J.J.; Grobbee, D.E.; van der Graaf, Y. Paraoxonase Variants Relate to 10-Year Risk in Coronary Artery Disease: Impact of a High-Density Lipoprotein-Bound Antioxidant in Secondary Prevention. J. Am. Coll. Cardiol. 2009, 54, 1238-1245. [CrossRef] [PubMed] 
32. Dantoine, T.F.; Drouet, M.; Debord, J.; Merle, L.; Cogne, M.; Charmes, J.P. Paraoxonase 1 192/55 Gene Polymorphisms in Alzheimer's Disease. Ann. N. Y. Acad. Sci. 2002, 977, 239-244. [CrossRef]

33. Janka, Z.; Juhász, A.; Rimanóczy, A.; Boda, K.; Márki-Zay, J.; Kálmán, J. Codon 311 (Cys -> Ser) Polymorphism of paraoxonase-2 Gene Is Associated With Apolipoprotein E4 Allele in Both Alzheimer's and Vascular Dementias. Mol. Psychiatry 2002, 7, 110-112. [CrossRef]

34. Ibrahim-Verbaas, C.A.; Zorkoltseva, I.V.; Amin, N.; Schuur, M.; Coppus, A.M.; Isaacs, A.; Aulchenko, Y.S.; Breteler, M.M.; Ikram, M.A.; Axenovich, T.I.; et al. Linkage Analysis for Plasma Amyloid Beta Levels in Persons With Hypertension Implicates A $\beta-40$ Levels to Presenilin 2. Hum. Genet. 2012, 131, 1869-1876. [CrossRef]

35. Wersching, H.; Guske, K.; Hasenkamp, S.; Hagedorn, C.; Schiwek, S.; Jansen, S.; Witte, V.; Wellmann, J.; Lohmann, H.; Duning, K.; et al. Impact of Common KIBRA Allele on Human Cognitive Functions. Neuropsychopharmacology 2011, 36, 1296-1304. [CrossRef]

36. Bessi, V.; Balestrini, J.; Bagnoli, S.; Mazzeo, S.; Giacomucci, G.; Padiglioni, S.; Piaceri, I.; Carraro, M.; Ferrari, C.; Bracco, L.; et al. Influence of ApoE Genotype and Clock T3111C Interaction With Cardiovascular Risk Factors on the Progression to Alzheimer's Disease in Subjective Cognitive Decline and Mild Cognitive Impairment Patients. J. Pers. Med. 2020, 10, 45. [CrossRef]

37. Armitage, J.; Holmes, M.V.; Preiss, D. Cholesteryl Ester Transfer Protein Inhibition for Preventing Cardiovascular Events: JACC Review Topic of the Week. J. Am. Coll. Cardiol. 2019, 73, 477-487. [CrossRef]

38. Poduslo, S.E.; Huang, R.; Spiro, A., 3rd. A Genome Screen of Successful Aging Without Cognitive Decline Identifies LRP1B by Haplotype Analysis. Am. J. Med. Genet. B Neuropsychiatr. Genet. 2010, 153B, 114-119. [CrossRef]

39. Raz, N.; Rodrigue, K.M.; Kennedy, K.M.; Land, S. Genetic and Vascular Modifiers of Age-Sensitive Cognitive Skills: Effects of COMT, BDNF, ApoE, and Hypertension. Neuropsychology 2009, 23, 105-116. [CrossRef] [PubMed]

40. Gong, S.; Su, B.B.; Tovar, H.; Mao, C.; Gonzalez, V.; Liu, Y.; Lu, Y.; Wang, K.S.; Xu, C. Polymorphisms within RYR3 Gene Are Associated With Risk and Age at Onset of Hypertension, Diabetes, and Alzheimer's Disease. Am. J. Hypertens. 2018, 31, 818-826. [CrossRef]

41. Sanders, A.E.; Wang, C.; Katz, M.; Derby, C.A.; Barzilai, N.; Ozelius, L.; Lipton, R.B. Association of a Functional Polymorphism in the Cholesteryl Ester Transfer Protein (CETP) Gene With Memory Decline and Incidence of Dementia. JAMA 2010, 303, 150-158. [CrossRef] [PubMed]

42. Giese, A.K.; Schirmer, M.D.; Dalca, A.V.; Sridharan, R.; Donahue, K.L.; Nardin, M.; Irie, R.; McIntosh, E.C.; Mocking, S.J.T.; Xu, H.; et al. White Matter Hyperintensity Burden in Acute Stroke Patients Differs by Ischemic Stroke Subtype. Neurology 2020, 95, e79-e88. [CrossRef] [PubMed]

43. Bos, D.; Wolters, F.J.; Darweesh, S.K.L.; Vernooij, M.W.; de Wolf, F.; Ikram, M.A.; Hofman, A. Cerebral Small Vessel Disease and the Risk of Dementia: A Systematic Review and Meta-Analysis of Population-Based Evidence. Alzheimers Dement. 2018, 14, 1482-1492. [CrossRef] [PubMed]

44. Ding, J.; Sigurðsson, S.; Jónsson, P.V.; Eiriksdottir, G.; Charidimou, A.; Lopez, O.L.; van Buchem, M.A.; Guðnason, V.; Launer, L.J. Large Perivascular Spaces Visible on Magnetic Resonance Imaging, Cerebral Small Vessel Disease Progression, and Risk of Dementia: The Age, Gene/Environment Susceptibility-Reykjavik Study. JAMA Neurol. 2017, 74, 1105-1112. [CrossRef]

45. Cannistraro, R.J.; Badi, M.; Eidelman, B.H.; Dickson, D.W.; Middlebrooks, E.H.; Meschia, J.F. CNS Small Vessel Disease: A Clinical Review. Neurology 2019, 92, 1146-1156. [CrossRef]

46. Chabriat, H.; Joutel, A.; Dichgans, M.; Tournier-Lasserve, E.; Bousser, M.G.; Cadasil. CADASIL. Lancet Neurol. 2009, 8, 643-653. [CrossRef]

47. Duering, M.; Csanadi, E.; Gesierich, B.; Jouvent, E.; Hervé, D.; Seiler, S.; Belaroussi, B.; Ropele, S.; Schmidt, R.; Chabriat, H.; et al. Incident Lacunes Preferentially Localize to the Edge of White Matter Hyperintensities: Insights Into the Pathophysiology of Cerebral Small Vessel Disease. Brain 2013, 136, 2717-2726. [CrossRef]

48. Moreton, F.C.; Razvi, S.S.; Davidson, R.; Muir, K.W. Changing Clinical Patterns and Increasing Prevalence in CADASIL. Acta Neurol. Scand. 2014, 130, 197-203. [CrossRef]

49. Opherk, C.; Gonik, M.; Duering, M.; Malik, R.; Jouvent, E.; Hervé, D.; Adib-Samii, P.; Bevan, S.; Pianese, L.; Silvestri, S.; et al. Genome-Wide Genotyping Demonstrates a Polygenic Risk Score Associated With White Matter Hyperintensity Volume in CADASIL. Stroke 2014, 45, 968-972. [CrossRef] 
50. Schilling, S.; DeStefano, A.L.; Sachdev, P.S.; Choi, S.H.; Mather, K.A.; DeCarli, C.D.; Wen, W.; Høgh, P.; Raz, N.; Au, R.; et al. APOE Genotype and MRI Markers of Cerebrovascular Disease: Systematic Review and Meta-Analysis. Neurology 2013, 81, 292-300. [CrossRef]

51. Carmelli, D.; Swan, G.E.; Reed, T.; Wolf, P.A.; Miller, B.L.; DeCarli, C. Midlife Cardiovascular Risk Factors and Brain Morphology in Identical Older Male Twins. Neurology 1999, 52, 1119-1124. [CrossRef] [PubMed]

52. Song, R.; Xu, H.; Dintica, C.S.; Pan, K.Y.; Qi, X.; Buchman, A.S.; Bennett, D.A.; Xu, W. Associations Between Cardiovascular Risk, Structural Brain Changes, and Cognitive Decline. J. Am. Coll. Cardiol. 2020, 75, 2525-2534. [CrossRef] [PubMed]

53. Kandel, B.M.; Avants, B.B.; Gee, J.C.; McMillan, C.T.; Erus, G.; Doshi, J.; Davatzikos, C.; Wolk, D.A. White Matter Hyperintensities Are More Highly Associated With Preclinical Alzheimer's Disease Than Imaging and Cognitive Markers of Neurodegeneration. Alzheimers Dement. 2016, 4, 18-27. [CrossRef] [PubMed]

54. Staekenborg, S.S.; Koedam, E.L.; Henneman, W.J.; Stokman, P.; Barkhof, F.; Scheltens, P.; van der Flier, W.M. Progression of Mild Cognitive Impairment to Dementia: Contribution of Cerebrovascular Disease Compared with Medial Temporal Lobe Atrophy. Stroke 2009, 40, 1269-1274. [CrossRef]

55. Sudre, C.H.; Bocchetta, M.; Cash, D.; Thomas, D.L.; Woollacott, I.; Dick, K.M.; van Swieten, J.; Borroni, B.; Galimberti, D.; Masellis, M.; et al. White Matter Hyperintensities Are Seen Only in GRN Mutation Carriers in the GENFI Cohort. NeuroImage Clin. 2017, 15, 171-180. [CrossRef]

56. Yu, Z.; Cao, S.; Wu, A.; Yue, H.; Zhang, C.; Wang, J.; Xia, M.; Wu, J. Genetically Confirmed CARASIL: Case Report With Novel HTRA1 Mutation and Literature Review. World Neurosurg. 2020, 143, 121-128. [CrossRef]

57. Lin, Y.F.; Smith, A.V.; Aspelund, T.; Betensky, R.A.; Smoller, J.W.; Gudnason, V.; Launer, L.J.; Blacker, D. Genetic Overlap Between Vascular Pathologies and Alzheimer's Dementia and Potential Causal Mechanisms. Alzheimers Dement. 2019, 15, 65-75. [CrossRef]

58. Tian, Y.; Chang, J.C.; Fan, E.Y.; Flajolet, M.; Greengard, P. Adaptor Complex AP2/PICALM, Through Interaction With LC3, Targets Alzheimer's APP-CTF for Terminal Degradation via Autophagy. Proc. Natl. Acad. Sci. USA 2013, 110, 17071-17076. [CrossRef]

59. Benedictus, M.R.; Prins, N.D.; Goos, J.D.; Scheltens, P.; Barkhof, F.; van der Flier, W.M. Microbleeds, Mortality, and Stroke in Alzheimer Disease: The MISTRAL Study. JAMA Neurol. 2015, 72, 539-545. [CrossRef]

60. Shams, S.; Granberg, T.; Martola, J.; Charidimou, A.; Li, X.; Shams, M.; Fereshtehnejad, S.M.; Cavallin, L.; Aspelin, P.; Wiberg-Kristoffersen, M.; et al. Cerebral Microbleeds Topography and Cerebrospinal Fluid Biomarkers in Cognitive Impairment. J. Cereb. Blood Flow Metab. 2017, 37, 1006-1013. [CrossRef] [PubMed]

61. Knol, M.J.; Lu, D.; Traylor, M.; Adams, H.H.; Romero, J.R.J.; Smith, A.V.; Fornage, M.; Hofer, E.; Liu, J.; Hostettler, I.C.; et al. Association of Common Genetic Variants With Brain Microbleeds: A Genome-Wide Association Study. Neurology 2020. [CrossRef] [PubMed]

62. Kim, M.; Bae, H.J.; Lee, J.; Kang, L.; Lee, S.; Kim, S.; Lee, J.E.; Lee, K.M.; Yoon, B.W.; Kwon, O.; et al. APOE epsilon2/epsilon4 Polymorphism and Cerebral Microbleeds on Gradient-Echo MRI. Neurology 2005, 65, 1474-1475. [CrossRef] [PubMed]

63. Maxwell, S.S.; Jackson, C.A.; Paternoster, L.; Cordonnier, C.; Thijs, V.; Al-Shahi Salman, R.; Sudlow, C.L. Genetic Associations With Brain Microbleeds: Systematic Review and Meta-Analyses. Neurology 2011, 77, 158-167. [CrossRef] [PubMed]

64. Schuur, M.; van Swieten, J.C.; Schol-Gelok, S.; Ikram, M.A.; Vernooij, M.W.; Liu, F.; Isaacs, A.; de Boer, R.; de Koning, I.; Niessen, W.J.; et al. Genetic Risk Factors for Cerebral Small-Vessel Disease in Hypertensive Patients From a Genetically Isolated Population. J. Neurol. Neurosurg. Psychiatry 2011, 82, 41-44. [CrossRef] [PubMed]

65. Li, H.Q.; Cai, W.J.; Hou, X.H.; Cui, M.; Tan, L.; Yu, J.T.; Dong, Q.; Alzheimer's Disease Neuroimaging Initiative. Genome-Wide Association Study of Cerebral Microbleeds on MRI. Neurotox. Res. 2020, 37, $146-155$. [CrossRef]

66. Yoo, J.S.; Ryu, C.H.; Kim, Y.S.; Kim, H.J.; Bushnell, C.D.; Kim, H.Y. Homocysteinemia Is Associated with the Presence of Microbleeds in Cognitively Impaired Patients. J. Stroke Cerebrovasc. Dis. 2020, $29,105302$. [CrossRef]

67. Chung, C.P.; Chen, J.W.; Chang, F.C.; Li, W.C.; Lee, Y.C.; Chen, L.F.; Liao, Y.C. Cerebral Microbleed Burdens in Specific Brain Regions Are Associated with Disease Severity of Cerebral Autosomal Dominant Arteriopathy with Subcortical Infarcts and Leukoencephalopathy. J. Am. Heart Assoc. 2020, 9, e016233. [CrossRef] 
68. Cohn-Hokke, P.E.; Holstege, H.; Weiss, M.M.; van der Flier, W.M.; Barkhof, F.; Sistermans, E.A.; Pijnenburg, Y.A.; van Swieten, J.C.; Meijers-Heijboer, H.; Scheltens, P. A Novel CCM2 Variant in a Family with Non-Progressive Cognitive Complaints and Cerebral Microbleeds. Am. J. Med. Genet. B Neuropsychiatr. Genet. 2017, 174, 220-226. [CrossRef]

69. Zhang, Y.; Ren, J. ALDH2 in Alcoholic Heart Diseases: Molecular Mechanism and Clinical Implications. Pharmacol. Ther. 2011, 132, 86-95. [CrossRef]

70. Zhu, Z.; Jiang, Y.; Cui, M.; Wang, Y.; Li, S.; Xu, K.; Zhang, K.; Zhu, C.; Xu, W.; Jin, L.; et al. ALDH2 rs671 Polymorphisms and the Risk of Cerebral Microbleeds in Chinese Elderly: The Taizhou Imaging Study. Ann. Transl. Med. 2020, 8, 229. [CrossRef]

71. Vermeer, S.E.; Prins, N.D.; den Heijer, T.; Hofman, A.; Koudstaal, P.J.; Breteler, M.M. Silent Brain Infarcts and the Risk of Dementia and Cognitive Decline. N. Engl. J. Med. 2003, 348, 1215-1222. [CrossRef] [PubMed]

72. Inaba, O.; Yamauchi, Y.; Sekigawa, M.; Miwa, N.; Yamaguchi, J.; Nagata, Y.; Obayashi, T.; Miyamoto, T.; Kamata, T.; Isobe, M.; et al. Atrial fibrillation type matters: Greater infarct volume and worse neurological defects seen in acute cardiogenic cerebral embolism due to persistent or permanent rather than paroxysmal atrial fibrillation. EP Eur. 2018, 20, 1591-1597. [CrossRef] [PubMed]

73. Conen, D.; Rodondi, N.; Müller, A.; Beer, J.H.; Ammann, P.; Moschovitis, G.; Auricchio, A.; Hayoz, D.; Kobza, R.; Shah, D.; et al. Relationships of Overt and Silent Brain Lesions With Cognitive Function in Patients with Atrial Fibrillation. J. Am. Coll. Cardiol. 2019, 73, 989-999. [CrossRef] [PubMed]

74. Madhavan, M.; Graff-Radford, J.; Piccini, J.P.; Gersh, B.J. Cognitive dysfunction in atrial fibrillation. Nature reviews. Cardiology 2018, 15, 744-756. [CrossRef]

75. Gutierrez, J.; Gil-Guevara, A.; Ramaswamy, S.; DeRosa, J.; Di Tullio, M.R.; Cheung, K.; Rundek, T.; Sacco, R.L.; Wright, C.B.; Elkind, M.S.V. Classification of Covert Brain Infarct Subtype and Risk of Death and Vascular Events. Stroke 2020, 51, 90-98. [CrossRef]

76. Chen, W.; Wang, S.; Lv, W.; Pan, Y. Causal Associations of Insulin Resistance With Coronary Artery Disease and Ischemic Stroke: A Mendelian Randomization Analysis. BMJ Open Diabetes Res. Care 2020, 8. [CrossRef]

77. Yan, A.; Cai, G.; Fu, N.; Feng, Y.; Sun, J.; Maimaiti, Y.; Zhou, W.; Fu, Y. Relevance Study on Cerebral Infarction and Resistin Gene Polymorphism in Chinese Han Population. Aging Dis. 2016, 7, 593-603. [CrossRef]

78. Notsu, Y.; Nabika, T.; Park, H.Y.; Masuda, J.; Kobayashi, S. Evaluation of Genetic Risk Factors for Silent Brain Infarction. Stroke 1999, 30, 1881-1886. [CrossRef]

79. Debette, S.; Bis, J.C.; Fornage, M.; Schmidt, H.; Ikram, M.A.; Sigurdsson, S.; Heiss, G.; Struchalin, M.; Smith, A.V.; van der Lugt, A.; et al. Genome-Wide Association Studies of MRI-Defined Brain Infarcts: Meta-Analysis from the CHARGE Consortium. Stroke 2010, 41, 210-217. [CrossRef]

80. van Rijn, M.J.; Bos, M.J.; Yazdanpanah, M.; Isaacs, A.; Arias-Vásquez, A.; Koudstaal, P.J.; Hofman, A.; Witteman, J.C.; van Duijn, C.M.; Breteler, M.M. Alpha-Adducin Polymorphism, Atherosclerosis, and Cardiovascular and Cerebrovascular Risk. Stroke 2006, 37, 2930-2934. [CrossRef]

81. Hirose, T.; Totsune, K.; Nakashige, Y.; Metoki, H.; Kikuya, M.; Ohkubo, T.; Hara, A.; Satoh, M.; Inoue, R.; Asayama, K.; et al. Influence of Adrenomedullin 2/Intermedin Gene Polymorphism on Blood Pressure, Renal Function and Silent Cerebrovascular Lesions in Japanese: The Ohasama Study. Hypertens. Res. 2011, 34, 1327-1332. [CrossRef] [PubMed]

82. Kim, J.O.; Jeon, Y.J.; Kim, O.J.; Oh, S.H.; Kim, H.S.; Shin, B.S.; Oh, D.; Kim, E.J.; Cho, Y.K.; Kim, N.K. Association Between Common Genetic Variants of $\alpha 2 \mathrm{~A}-, \alpha 2 \mathrm{~B}$ - and $\alpha 2 \mathrm{C}$-adrenoceptors and the Risk of Silent Brain Infarction. Mol. Med. Rep. 2014, 9, 2459-2466. [CrossRef] [PubMed]

83. Song, J.; Kim, O.J.; Kim, H.S.; Bae, S.J.; Hong, S.P.; Oh, D.; Kim, N.K. Endothelial Nitric Oxide Synthase Gene Polymorphisms and the Risk of Silent Brain Infarction. Int. J. Mol. Med. 2010, 25, 819-823. [CrossRef] [PubMed]

84. Han, I.B.; Kim, O.J.; Ropper, A.E.; Kim, H.S.; Cho, Y.K.; Teng, Y.D.; Kim, N.K. Association Between Kinase Insert Domain-Containing Receptor Gene Polymorphisms and Silent Brain Infarction: A Korean Study. J. Neurol. Sci. 2012, 318, 85-89. [CrossRef]

85. Kohara, K.; Fujisawa, M.; Ando, F.; Tabara, Y.; Niino, N.; Miki, T.; Shimokata, H.; NILS-LSA Study. MTHFR Gene Polymorphism as a Risk Factor for Silent Brain Infarcts and White Matter Lesions in the Japanese General Population: The NILS-LSA Study. Stroke 2003, 34, 1130-1135. [CrossRef] 
86. Serizawa, M.; Nabika, T.; Ochiai, Y.; Takahashi, K.; Yamaguchi, S.; Makaya, M.; Kobayashi, S.; Kato, N. Association Between PRKCH Gene Polymorphisms and Subcortical Silent Brain Infarction. Atherosclerosis 2008, 199, 340-345. [CrossRef]

87. Cho, Y.; Kim, J.O.; Lee, J.H.; Park, H.M.; Jeon, Y.J.; Oh, S.H.; Bae, J.; Park, Y.S.; Kim, O.J.; Kim, N.K. Association of Reduced Folate carrier-1 (RFC-1) Polymorphisms With Ischemic Stroke and Silent Brain Infarction. PLOS ONE 2015, 10, e0115295. [CrossRef]

88. Zhao, J.; Zheng, L.; Fei, Q.; Fu, Y.; Weng, Y.; Wu, H.; Li, H.; Jun, Q.; Shao, J.; Xu, Y. Association of Thromboxane A2 Receptor Gene Polymorphisms With Cerebral Infarction in a Chinese Population. Neurol. Sci. 2013, 34, 1791-1796. [CrossRef]

89. Matsui, T.; Arai, H.; Yuzuriha, T.; Yao, H.; Miura, M.; Hashimoto, S.; Higuchi, S.; Matsushita, S.; Morikawa, M.; Kato, A.; et al. Elevated Plasma Homocysteine Levels and Risk of Silent Brain Infarction in Elderly People. Stroke 2001, 32, 1116-1119. [CrossRef]

90. Kim, O.J.; Hong, S.H.; Oh, S.H.; Kim, T.G.; Min, K.T.; Oh, D.; Kim, N.K. Association Between VEGF Polymorphisms and Homocysteine Levels in Patients With Ischemic Stroke and Silent Brain Infarction. Stroke 2011, 42, 2393-2402. [CrossRef]

91. Hohman, T.J.; Bell, S.P.; Jefferson, A.L.; Alzheimer's Disease Neuroimaging Initiative. The Role of Vascular Endothelial Growth Factor in Neurodegeneration and Cognitive Decline: Exploring Interactions with Biomarkers of Alzheimer Disease. JAMA Neurol. 2015, 72, 520-529. [CrossRef] [PubMed]

92. Elahi, F.M.; Casaletto, K.B.; La Joie, R.; Walters, S.M.; Harvey, D.; Wolf, A.; Edwards, L.; Rivera-Contreras, W.; Karydas, A.; Cobigo, Y.; et al. Plasma Biomarkers of Astrocytic and Neuronal Dysfunction in Early- and Late-Onset Alzheimer's Disease. Alzheimers Dement. 2020, 16, 681-695. [CrossRef] [PubMed]

Publisher's Note: MDPI stays neutral with regard to jurisdictional claims in published maps and institutional affiliations. 